\title{
Review
}

\section{Relationship between Thermometry Results and Tumor Response in Thermoradiotherapy}

\section{YASUMASA NISHIMURA ${ }^{1 *}$, and MASAHIRO HIRAOKA ${ }^{2}$}

${ }^{1}$ Department of Radiology, Kinki University School of Medicine, Osaka-Sayama, Japan.

${ }^{2}$ Department of Radiology, Faculty of Medicine, Kyoto University, Kyoto, Japan.

\begin{abstract}
Clinical results of thermoradiotherapy for various tumors at Kyoto University were reviewed with a special attention to the relationship between thermometry results and tumor response. Thermometry for superficial and subsurface tumors were satisfactory, and continuous multipoint thermometry could be performed for the tumors. Thermal parameters predicting complete tumor regression were minimum tumor temperature, minimum equivalent time at $43{ }^{\circ} \mathrm{C}$, and number of the treatment goal heat sessions. On the other hand, thermal data obtained were insufficient for deep-seated tumors, and no significant relationship could be demonstrated between tumor response and thermal parameters for deep-seated tumors. On the other hand, significant correlation between tumor degeneration and intravesical temperatures was demonstrated for bladder tumors. Until non-invasive thermometry is available clinically, temperature measurements of bladder or rectal cavity can be an alternative method of direct insertion of thermal probes into the pelvic tumors. Because a significant relationship between certain thermal parameters and tumor response was demonstrated for superficial tumors, stringent quality control of thermometry is required for the success of clinical hyperthermia of both superficial and deep-seated tumors.
\end{abstract}

Key Words : hyperthermia, thermometry, tumor response, thermo-radiotherapy

\section{Introduction}

Hyperthermia (HT) combined with radiation therapy (RT) is regarded as one of the effective and safe treatment modalities for refractory malignant tumors. Biologically, thermal effects for tumors and normal tissues are dependent on both heating temperature and heating time. Therefore, stringent quality control of heating devices, thermometry, and treatment documentation are required for the success of clinical HT. However, only an invasive method of inserting thermal sensors is available at present time to measure intratumoral temperatures in clinical hyperthermia. Therefore, it is often difficult to measure tumor temperatures satisfactorily especially in the treatment of deep-seated tumors.

We have treated many malignant tumors including superficial and deep-seated tumors by various types of heating devices at the Department of Radiology, Kyoto University since 1979. Clinical results of hyperthermia at Kyoto University have been reported in various papers. To reveal the relationship between tumor response and

Received 28 July 1998, Accepted 31 July 1998. *Corresponding author, Tel: 81-723-66-0221, ext.3130; Fax: 81-723-68-2388;

E-mail: ynishi@med.kindai.ac.jp 
thermometry results, we have reviewed our clinical results of superficial and deep-seated tumors. In addition, we discussed the practical methods of thermometry in clinical hyperthermia.

\section{Materials and Methods}

In this mini-review, we have reviewed thermometry results and tumor response in our clinical papers published since 1990. Table I shows the numbers of tumors included in the studies. There are 10 papers including two papers on new HT devices for superficial and subsurface tumors ${ }^{1,2)}$ and eight papers on site-specific clinical results of various tumor sites including breast, soft tissues, lung, liver, stomach, pancreas, colorectum, and bladder ${ }^{3-10}$.

Table I. Clinical results of hyperthermia at Kyoto University.

\begin{tabular}{lcc}
\hline $\begin{array}{l}\text { HT devices or primary sites } \\
\text { (ref. No.) }\end{array}$ & Year & No. of tumors \\
\hline New HT devices & 1995 & 57 tumors \\
430 MHz MW (1) & 1997 & 38 tumors \\
0.5-1.5 MHz US(2) & & \\
Site-specific clinical results & 1990 & 30 tumors \\
Breast cancer (3) & 1992 & 20 tumors \\
Lung cancer (4) & 1992 & 35 tumors \\
Colorectal cancer(5) & 1994 & 28 tumors \\
Bladder cancer (6) & 1995 & 31 tumors \\
Soft tissue tumors (7) & 1995 & 21 tumors \\
Gastric cancer (8) & 1996 & 15 tumors \\
Pancreas cancer (9) & 1997 & 140 tumors \\
Liver tumors (10) & & \\
\hline
\end{tabular}

\section{Hyperthermia and radiation therapy}

Three different HT devices were used in these studies. An $8 \mathrm{MHz}$ radiofrequency (RF) capacitive heating device was used for deep-seated tumors and large superficial tumors, whereas a $430 \mathrm{MHz}$ microwave (MW) heating device using a lens applicator and a $0.5-1.5 \mathrm{MHz}$ ultrasound (US) heating device were used for localized superficial and subsurface tumors. Detailed descriptions of the HT devices have been described elsewhere ${ }^{2,4,111}$.

Hyperthermia was given 10-30 min. after RT once or twice weekly for 1-14 sessions. Our treatment goal of each HT session was to obtain all monitored intratumor points of $>41^{\circ} \mathrm{C}$ for $30 \mathrm{~min}$. For superficial and subsurface tumors, the steady-state temperature was achieved within $10 \mathrm{~min}$., and was kept for 40-50 min. thereafter. For deep-seated tumors, on the other hand, it took 20-30 min. to reach the steady-state temperature, and it was not possible to achieve the intended treatment goal in most deep-seated tumors. For these patients, we administered HT at the maximum power tolerable by the patient, and terminated after power had been on for 40-60 min.

For most tumors excluding liver tumors, HT was combined with RT. For most tumors, definitive RT doses of 50-70 Gy were given by conventional fractionation in conjunction with HT, although some tumors including soft tissue tumors were treated by hypofractionation (4 Gy per fraction, twice a week) in the dose range of 24-54 Gy ${ }^{7}$. For the recurrent tumors after previous RT, a total of 20-50 Gy using conventional fractionation or hypofractionation was delivered. In the preoperative RT for bladder cancer, a total of $24 \mathrm{~Gy} / 6$ fractions $/ 2$ weeks was combined with 4 sessions of regional $\mathrm{HT}^{6}$. 


\section{Thermometry and definition of thermal parameters}

In the MW heating device and the US heating device, continuous multipoint thermometry was available 1,2,11). Invasive thermometry was performed for all superficial and subsurface tumors treated by the MW heating device and the US heating device ${ }^{1,2}$. Usually, one or two multipoint thermal probes were inserted into the tumor through angiocatheters, and skin temperature at the center of HT field was also monitored. In the multipoint thermal probes, 3-6 thermal sensors were located at $0.8-1 \mathrm{~cm}$ intervals.

For deep-seated tumors treated by the $8 \mathrm{MHz}$ RF heating device, one or two single-point thermal sensors were inserted into the tumor as deeply as possible with the aid of a diagnostic US device, CT scan, or palpation. In this case, a temperature of the deepest point from the surface was monitored continuously, and thermal distribution within the tumor and the surrounding normal tissues was obtained by moving the sensor at $1 \mathrm{~cm}$ intervals along each catheter track. Temperature maps were usually obtained twice 15-25 min. after the start of HT, and at the end of treatment ${ }^{5}$. For bladder tumors, temperatures inside the bladder and rectum were monitored continuously during heat treatment, because direct insertion of thermal probes into bladder tumors was not easy ${ }^{6}$.

Several thermal parameters have been defined as follows, although there were slight changes in the definition in each paper. Tmax, Tmin, and Tav are the maximum, minimum, and average temperatures of all recorded intratumoral temperatures during a steady state and the end of treatment. Eq43 max, Eq43 min, and Eq43 av are the maximum, minimum, and average equivalent time at $43^{\circ} \mathrm{C}$ among all intratumoral sensor points. Means of Tmax, Tmin, and Tav were calculated over all HT sessions for each tumor, whereas Eq43max, Eq43min, and Eq43av were summed up respectively over the entire course of HT sessions for each tumor ${ }^{1,5)}$. For bladder tumors, only Tav of intravesical temperatures was obtained because no direct measurement of temperatures in the bladder tumors was performed ${ }^{6}$.

In terms of quality of HT sessions, we defined two types of HT session. When all monitored intratumoral points could be heated to $>41^{\circ} \mathrm{C}$ for $>30$ min., we defined such excellent sessions as treatment goal HT sessions. Similarly, effective HT sessions were defined when at least one intratumor point could be heated to $>42^{\circ} \mathrm{C}$ for $>20$ min. ${ }^{1)}$.

\section{Results}

\section{Superficial and subsurface tumors}

For subsurface and superficial tumors, continuous multipoint thermometry was possible for every heat session ${ }^{1,2)}$. Mean numbers of intratumor thermometry points for these subsurface tumors were 3.7 points (range; 2-6) for the $430 \mathrm{MHz}$ MW HT device, and 4.3 points (range; 1-7) for the US HT device.

Significant relationship between tumor response and several thermal parameters was demonstrated for these superficial and subsurface tumors. Fig. 1 shows complete response (CR) rate as a function of number of HT sessions for tumors treated with a $430 \mathrm{MHz}$ MW heating device ${ }^{1)}$. With the increase in the number of the treatment goal HT sessions from zero to 4-5, the corresponding CR rate was increased from $39 \%$ to $78 \%$. On the other hand, no such increase was observed for the number of total HT sessions or effective HT sessions. Fig. 2 show the $\mathrm{CR}$ rate as a function of Eq43. The CR rate increased from approximately $30 \%$ to $75 \%$ with increasing Eq43 min. However, no such dose-response relationship was observed for Eq43 av and Eq 43 max. Similarly 


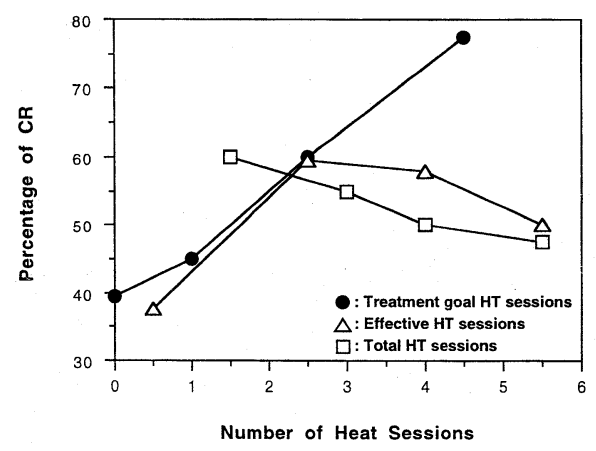

Fig. 1. The relationship between number of heat sessions and complete response (CR) rate in superficial and subsurface tumors treated with a $430 \mathrm{MHz}$ heating device. The figure was modified from Ref. No. 1 with the authors' permission.

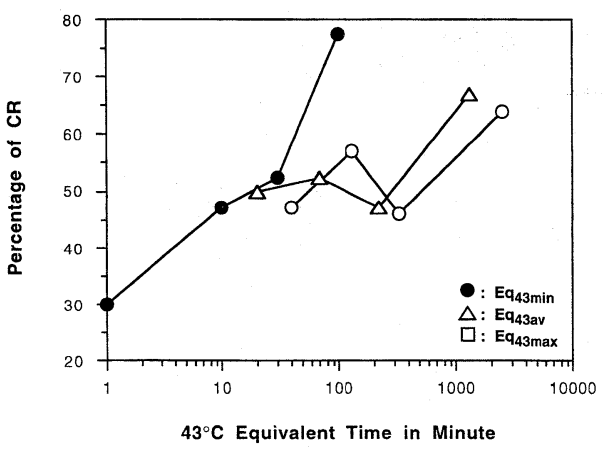

Fig. 2. The relationship between $43^{\circ} \mathrm{C}$ equivalent time and complete response (CR) rate. The figure was modified from Ref. No. 1 with the authors' permission.

dose-response relationship was observed between Tmin and the CR rate. Thus, thermal parameters predicting CR were number of the treatment goal HT sessions, Eq43 min, and Tmin.

For superficial and subsurface tumors treated with US heating devices, Tav and Tmin of tumors showing CR or partial response (PR) were slightly higher than those of tumors showing no response (NC), although no significant relationship between $\mathrm{CR}$ rate and thermal parameters was observed ${ }^{2}$. In the analysis, both thermal parameters and tumor response rate decreased with tumor depth ${ }^{2)}$. Tumor size and tumor depth may be stronger prognostic factors for tumor response than the thermal parameters, which was also noted in the analysis of the MW heating device ${ }^{1}$.

\section{Deep-seated tumors}

Thermometry was not easy for deep-seated tumors compared to superficial tumors. In most deep-seated tumors, only one thermal probe was inserted into the tumor. Summary of the thermometry results for deepseated tumors are shown in Table II. Thermometry was most difficult for hepatic, gastric, and pancreatic tumors, followed by rectal tumors. On the other hand, thermometry was performed for almost all breast, lung, and soft tissue tumors. Intratumoral temperature distribution was measured by moving thermal proves

Table II. Summary of the thermometry results for deep-seated tumors

\begin{tabular}{lcl}
\hline Tumor sites & Thermometry & Temp. distribution \\
\hline breast : & $97 \%(176 / 182 *)$ & $64 \%(116 / 182 *)$ \\
soft tissue : & $100 \%(30 / 30)$ & $73 \%(22 / 30)$ \\
lung : & $100 \%(20 / 20)$ & $85 \%(17 / 20)$ \\
liver : & $55 \%(77 / 140)$ & $55 \%(77 / 140)$ \\
pancreas : & $67 \%(10 / 15)$ & \\
stomach : & $62 \%(13 / 21)$ & $62 \%(13 / 21)$ \\
rectum: & $84 \%(169 / 201 *)$ & $57 \%(115 / 201 *)$ \\
bladder: & $100 \%(28 / 28)$ & \\
& (intravesical temp.) & \\
\hline
\end{tabular}

*; Percentage of thermometry was calculated based on the number of HT sessions. Others were percentage of thermometry per tumor. during and at the end of HT session only for $55-85 \%$ of the tumors, although temperature distribution could not be obtained for pancreatic and bladder tumors (Table II). Because continuous multipoint thermometry was not possible for most heat sessions, equivalent time at $43 \mathrm{C}$ could not be calculated for deep-seated tumors.

As the thermometry data obtained were insufficient, no significant correlation between thermal parameters and tumor regression was demonstrated for gastric, pancreatic, hepatic, and lung cancers ${ }^{4,8-10)}$. On the other hand, some correlation between thermal parameters (Tav and Tmin) and tumor response were found for rectal cancer and 
breast cancer ${ }^{3,5)}$. Table III shows the relationship between Tav and tumor response for advanced colorectal cancer treated by thermoradiotherapy ${ }^{5)}$. A better response rate of $67 \%$ was obtained in the tumors with Tav of $>42^{\circ} \mathrm{C}$, although there was no significant difference between the RT alone group $(\mathrm{p}<0.10)$.

For soft tissue tumors and lung cancer, higher thermal
Table III. Tumor response according to Tav for advanced colorectal cancer

\begin{tabular}{llccl}
\hline & \multicolumn{4}{l}{ Tumor response } \\
Treatment & CR & PR & NR & CR+PR \\
\hline RT alone & 2 & 8 & 18 & $36 \%(10 / 28)$ \\
RT+HT $\left(\operatorname{Tav}>42^{\circ} \mathrm{C}\right)$ & 3 & 7 & 5 & $67 \%(10 / 15)$ \\
$\left(\operatorname{Tav}<42^{\circ} \mathrm{C}\right)$ & 1 & 7 & 9 & $47 \%(8 / 17)$ \\
\hline
\end{tabular}

The table was rewritten from Ref. No. 5 with the authors' permission. parameters were closely related to the appearance of intratumor low density area (LDA) on CT, reflecting massive coagulation necrosis ${ }^{4,7)}$. Intratumor LDA was classified into three types according to its percent area in the tumor; $<50 \%$ as type I, $50-80 \%$ as type II, and $>80 \%$ as type III ${ }^{4,7)}$. In soft tissue tumors, six tumor showed type III LDA on post-treatment CT. Among the six tumors, two tumors regressed completely in the follow-up studies, one tumor demonstrated no malignant cells in the resected specimen, and the remaining three tumors did not regrow in the further follow-up studies ${ }^{7}$. Thus, intratumor LDA on the post-treatment CT is reflecting the effect of HT.

For bladder cancer, histological examination of the surgical specimen was performed after preoperative RT or preoperative thermoradiotherapy ${ }^{6}$. In terms of thermometry, a significant relationship between averaged intravesical temperatures and rectal temperatures was demonstrated for bladder tumors ${ }^{6)}$. Histological degeneration of tumor cells were defined as changes higher than Grade IIb of the Oboshi-Shimosato classification. Table IV shows the results of the histological analysis. Bladder tumors with high average intravesical temperature $\left(>41.5^{\circ} \mathrm{C}\right)$ showed significantly higher incidence of tumor degeneration than bladder tumors treated with preoperative RT alone or tumors with low average intravesical temperature of less than $41.5^{\circ} \mathrm{C}(\mathrm{p}<0.05)^{6}$.

\begin{tabular}{|c|c|c|c|c|}
\hline \multirow[t]{2}{*}{ Treatment } & \multicolumn{2}{|c|}{ Degeneration } & \multirow{2}{*}{\multicolumn{2}{|c|}{$\begin{array}{l}\text { Percentage of tumors } \\
\text { with degeneration }\end{array}$}} \\
\hline & + & - & & \\
\hline RT alone & 8 & 12 & $40 \%(8 / 20)$ & \\
\hline $\mathrm{RT}+\mathrm{HT}\left(\mathrm{Tav}>41.5^{\circ} \mathrm{C}\right)$ & 10 & 2 & $83 \%(10 / 12)$ & $\mathrm{p}<0.05$ \\
\hline$\left(\operatorname{Tav}<41.5^{\circ} \mathrm{C}\right)$ & 7 & 9 & $44 \%(7 / 16)$ & \\
\hline
\end{tabular}

Tav; average intravesical temperature

The table was rewritten from Ref. No. 6 with the authors' permission.

\section{Discussion}

For superficial and subsurface tumors, thermometry was performed satisfactorily, and significant correlation between thermal parameters and tumor response was demonstrated. Therefore, continuous multipoint thermometry should be done for all subsurface and superficial tumors. Invasive thermometry is not so dangerous for patients and thermal parameters obtained predict clinical outcome of the tumors.

In the univariate analysis for superficial and subsurface tumors ${ }^{1)}$, Tmin, Tav, Eq43 min, and number of treatment goal sessions were significant thermal parameters for predicting CR. Among the thermal parameters, Eq43 min and number of the treatment goal HT sessions seem most important because these parameters incorporate both time and minimum tumor temperatures. These results indicate the importance of quality and quantity of HT session on the treatment outcome of thermoradiotherapy. 
On the other hand, continuous multipoint thermometry is not easy for deep-seated tumors. Direct temperature measurements for deep-seated tumors may sometime result in serious complications. In addition, thermal data obtained were usually insufficient for large deep-seated tumors, because only temperatures of small parts of the tumor can be obtained by inserting one or two thermal sensors into large deep-seated tumors. Therefore, Tmin is not a true minimum temperature for the deep-seated tumors. No significant correlation was observed for gastric, pancreatic, hepatic, and lung cancers, although some relationship between thermal parameters (Tav and Tmin) and tumor response for rectal and breast cancers were demonstrated. Apparently, the poor quality of thermometry for deep-seated tumors attributed the weak relationship between thermometry results and tumor response for deepseated tumors.

Well-heated deep-seated tumors regress slowly, showing intratumor low density area on CT. The appearance of LDA was closely related to the thermal parameters in soft tissue tumors, lung cancer, and colorectal cancer ${ }^{4,5,7)}$. Histologically, these LDA reflect massive coagulation necrosis. In addition, tumors with type III LDA showed good clinical outcome including delayed CR, pathological CR, or no tumor regrowth for long time. Thus, the intratumor LDA on post-treatment CT is a good parameter for assessing tumor response in thermoradiotherapy.

For bladder tumors, significant correlation between tumor degeneration and intravesical bladder temperatures was demonstrated. In addition, intravesical bladder temperatures correlated significantly with rectal temperatures. Thus, at least for pelvic tumors, temperature measurements of bladder or rectal cavity can be an alternative method of direct insertion of thermal probes into tumors. For thoracic and upper abdominal deep-seated tumors, such alternative methods of thermometry may be possible, although significant correlation between intratumor temperatures and intraluminal temperatures should be demonstrated.

As a non-invasive thermometry system is not available clinically, we must monitor the quality of HT sessions by invasive thermometry methods. For superficial tumors, continuous multipoint thermometry should be done every time. However, for deep-seated tumors, invasive measurements of intratumor temperatures are not easy. Therefore, temperature measurements of bladder or rectal cavity may be an alternative method of direct insertion of thermal probes for the pelvic tumors.

\section{Acknowledgments}

This work was supported in part by Grant-in-Aid from the Ministry of Education, Science, Sports, and Culture, Japan.

\section{References}

1) Nishimura Y., Hiraoka M., Mitsumori M., Okuno Y., Li Y.P., Masunaga S., Koishi M., Akuta K., Abe M.: Thermoradiotherapy for superficial and subsurface tumors: analysis of thermal parameters and tumor response. Int J Hyperthermia, 11: 603-614, 1995.

2) Mitsumori M., Hiraoka M., Okuno Y., Nishimura Y., Li Y.P., Fujishiro S., Nagata Y., Abe M., Koishi M., Sano T., Marume T., Takayama N.: A phase I and II clinical trial of a newly developed ultrasound hyperthermia system with an improved planar transducer. Int J Radiat Oncol Biol Phys, 36: 1169-1175, 1996.

3) Masunaga S., Hiraoka M., Takahashi M., Jo S., Akuta K., Nishimura Y., Nagata Y., Abe M.: Clinical results of thermoradiotherapy for locally advanced and/or recurrent breast cancer: Comparison of results with radiotherapy alone. Int $\mathbf{J}$ Hyperthermia, 6: 487-497, 1990.

4) Hiraoka M., Masunaga S., Nishimura Y., Nagata Y., Jo S., Akuta K., Li Y.P., Takahashi M., Abe M.: Regional hyperthermia 
combined with radiotherapy in the treatment of lung cancers. Int J Radiat Oncol Biol Phys, 22: 1009-1014, 1992.

5) Nishimura Y., Hiraoka M., Akuta K., Jo S., Nagata Y., Masunaga S., Takahashi M., Abe M.: Hyperthermia combined with radiation therapy for primarily unresectable and recurrent colorectal cancer. Int J Radiat Oncol Biol Phys, 23: 759-768, 1992.

6) Masunaga S., Hiraoka M., Akuta K., Nishimura Y., Nagata Y., Jo S., Takahashi M., Abe M., Terachi T., Oishi K., Yoshida O.: Phase I/II trial of preoperative thermoradiotherapy in the treatment of urinary bladder cancer. Int J Hyperthermia, 10: 31-40, 1994.

7) Hiraoka M., Nishimura Y., Masunaga S., Koishi M., Mitsumori M., Li Y.P., Nagata Y., Akuta K., Takahashi M., Abe M.: Clinical results of thermoradiotherapy of soft tissue tumors. Int J Hyperthermia, 11: 365-377, 1995.

8) Nagata Y., Hiraoka M., Nishimura Y., Masunaga Y., Akuta K., Li Y.P., Koishi M., Mitsumori M., Okuno Y., Takahashi M., Abe M.: Clinical experiences in the thermoradiotherapy for advanced gastric cancer. Int J Hyperthermia, 11: 501-510, 1995.

9) Shibamoto Y., Nishimura Y., Abe M. Intraoperative radiotherapy and hyperthermia for unresectable pancreatic cancer. HepatoGastroenterology, 43: 326-332, 1996.

10) Nagata Y., Hiraoka M., Nishimura Y., Masunaga S., Mitsumori M., Okuno Y., Fujishiro M., Kanamori S., Horii N., Akuta K., Sasai K., Abe M., Fukuda Y. Clinical results of radiofrequency hyperthermia for malignant liver tumors. Int J Radiat Oncol Biol Phys, 38: 359-365, 1997.

11) Nishimura Y., Akuta K., Hiraoka M., Masunaga S., Nagata Y., Takahashi M., Abe M., Koizumi K. Initial clinical results of a 430 MHz microwave hyperthermia system using a lens applicator. Radiother Oncol, 17: 219-227, 1990. 


\title{
温熱併用放射線治療における温度因子と治療効果の関係
}

\author{
西村 恭昌 1 - 平岡 真寛 2
}

'近畿大学医学部放射線医学教室

2京都大学医学部放射線医学教室

要 旨: 温度因子と治療効果の関係に注目して京都大学に打りる温熱併用放射線治療成績を再分析した。 表在性腫瘍に対する温度測定結果は満足すべきもので, 多点連続測温が可能であった。その結果, 腫瘍最 低温度, 最低 $43^{\circ} \mathrm{C}$ 等価加温時間, 目的の温熱治療が完遂できた温熱治療の回数の 3 因子が, 腫瘍の完全 消失と有意に関連する温度因子であった。一方，深部腫瘍に対する温度デー夕は不十分で，深部腫瘍に対 しては治療効果と相関する有意な温度因子は明らかにできなかった。一方, 膀胱内温度を測定した膀胱癌 では, 術後標本での腫瘍の変性と膀胱内温度に相関が認められた。非侵襲的温度測定が臨床的に可能にな るまでは，膀胱内や直腸内の温度測定が，骨盤部腫腸の代換温度測定法となる可能性が示唆された．表在 性腫瘍では, 温度因子と腫瘍効果に相関が示されており, 表在性腫瘍および深部腫瘍に対する温熱療法を 成功させるには，質の高い温度測定が必要と考えられた。 